\title{
MECHANISM OF ACTION AND NEUTRALIZING AGENTS FOR SURFACE-ACTIVE MATERIALS UPON MICROORGANISMS
}

\author{
By C. A. Lawrence \\ Universily of Michigan, Ann Arbor, Michigan
}

In this paper, it would seem desirable to orient the informed, as well as the uninformed, workers in the fields of disinfection and antisepsis as to some of the theories that have been advanced concerning the possible mechanisms of action of "surface-active agents" upon microorganisms. Since several of the papers presented in this monograph include a discussion of "neutralizers," "inactivators," or "antidotal" substances which may be used to counteract the antibacterial activity of surface-active germicides, brief mention will also be made of this subject.

Some of the compounds that were incorporated on the nucleus of hexamethylenetetramine by Jacobs and Heidelberger ${ }^{1-8}$ may be considered surface-active agents. In one of the early publications by Jacobs, ${ }^{9}$ certain conclusions were drawn in respect to the correlation between chemical configuration of the hexamethylenetetramines and their degree and specificity of activity against bacteria. Note was made of the fact that the bactericidal nature of the compounds was primarily concerned with the hexamethylenetetramine portion of the molecule, whereas the degree of activity was determined by the nature of the molecular groups attached to the latter. Jacobs also demonstrated that the added groups on hexamethylenetetramine were responsible for the derivatives, showing, in some instances, incompatibility with serum and the toxicity of others.

In studying the mechanism of action of a homologous series of alcohols of the primary, secondary, and tertiary types, Cowles ${ }^{10}$ found that, against Eberthella typhosa and Staphylococcus aureus, the germicidal and surface activities increased with an increase in chain lengths of the alcohols. There appeared to be a close correlation between the germicidal action and surface activity of the alcohols, which suggested to him that these organic compounds may depend upon adsorption primarily and upon toxicity to bacterial protoplasm secondarily.

In studying the "detoxifying" action of various agents against bacteria, Harris and Bunker ${ }^{11}$ found that tetramethylammonium chloride would destroy the virulence of bacteria under certain conditions without necessarily killing them. Inhibition of certain physiological processes of the bacterial cells were brought about by the germicide; yet the production of antibodies in the host continued. This action, observed with the tetanus organism, was attributed not to the surface-tension depressant action of the quaternary ammonium compound, nor to the particular anion or cation, but to the configuration of the molecule as a whole.

Neter $^{12}$ was able to demonstrate that amounts of as little as $0.1 \mathrm{mg}$. of a quaternary ammonium salt would detoxify 10 minimum lethal doses of tetanus toxin. This action was independent of any changes that could be attributed to the influence of $\mathrm{pH}$. Serum would inhibit this detoxifying 
action. No mention was made in the report as to whether or not the surface-active compound affected the antigenic properties of the detoxified toxin. Neter ${ }^{13}$ also presented the results of his observations on the effect of a surface-active cationic germicide upon plasma coagulation by staphylococci and upon fibrinolysis by streptococci. The compound in relatively high dilutions delayed the clotting of oxalated human plasma by staphylococcus cultures and inhibited fibrinolysis by hemolytic streptococci.

Holmes $^{14}$ noted that the antigen in serological systems was not affected by an anionic detergent and that no change could be evidenced on bacteria, since the latter could still absorb antibody after treatment. The same agent also failed to denature antiserum in the concentrations tested. While alcohols were found not to alter the course of the reactions in precipitation and agglutination tests, the soaps used in the investigation were found to inhibit immunological reactions. This interference was attributed to an increase in the electrical charge on the organisms by the anionic soaps. Cationic detergents, on the other hand, acted in an opposite manner by spontaneously agglutinating the organisms due to markedly lowering their charge. Thus, the latter compounds decreased the stability of the antigen and also caused a nonspecific precipitation of serum.

Miller, Baker, and Harrison ${ }^{15}$ showed that a surface-active quaternary ammonium germicide would exert a pronounced inhibitory effect on respiration and glycolysis of organisms associated with dental caries. Concentrations as low as $\mathbf{M} / 10,000$ of the compound were effective in a matter of a few minutes. This action was complete and irreversible, inasmuch as the activity was not regained by washing the treated cells and again testing them for metabolic activity in fresh medium. In continuing these investigations, Miller and his co-workers ${ }^{16-18}$ observed that the quaternary ammonium germicides (cationics) would inhibit the metabolism of Grampositive and Gram-negative bacteria in concentrations ranging from 1/3000 to $1 / 60,000$. The anionic surface-active compounds, on the other hand, showed complete inhibition only against the Gram-positive bacteria and here at a dilution of $1 / 3000$. These workers implied that the complete absence of bactericidal action of anionic detergents and diminished activity of some of the cationic detergents against Gram-negative organisms may be related to differences in content, type, or cellular arrangement of phospholipids in the Gram-negative as compared to the Gram-positive bacteria.

Partial substantiation of the point just mentioned may be found in the report by Baker, Harrison, and Miller, ${ }^{16}$ in which an investigation was made of the interfering action of phospholipids upon the antibacterial activity of a number of synthetic detergents. They had previously found that a combination of an anionic detergent with a cationic detergent (quaternary ammonium compound) would often result in the formation of a precipitate. This reaction was accompanied by an interference of the inhibiting action on bacterial metabolism by the anionic or cationic detergent. However, when phospholipids were added to a cationic detergent before or simultaneously with the addition of the latter to a bacterial suspension, although interference in metabolism of the cells would also occur, the reaction was 
considered quite different from that observed when cationic and anionic detergents were combined.

Using the manometric technique described by Baker and his co-workers, Ordal and Borg ${ }^{19}$ studied the oxidation of lactate by molecular oxygen as compared with the anaerobic oxidation of methylene blue in testing the activities of an anionic and a cationic detergent against $S$. aureus and Escherichia coli. These investigators found that the lactate dehydrogenase of $S$. aureus is more susceptible to the action of both anionic and cationic surface-active agents than that of $E$. coli. While both types of detergents inhibited the oxidation of lactate by $S$. aureus, only the cationic detergent (quaternary ammonium compound) inhibited the oxidation of lactate by E. coli. With $S$. aureus, little difference was noted in the concentrations of both types of surface-active compounds required to inhibit the oxidation of lactate by oxygen, as compared to the oxidation by methylene blue.

Sevag and Ross $^{20}$ studied the mechanism of inhibitory action of a quaternary ammonium surface-active agent against yeast cells. A concentration of $1 / 1000$ of the compound caused a marked fading or abolishment of the adsorption bands of a preparation of cytochrome $\mathrm{C}$ and yeast cells. In their manometric measurements, a $1 / 35,000$ dilution of the quaternary ammonium germicide caused complete inhibition of the oxygen consumption of $p$-phenylenediamine in yeast cells, and the aerobic and anaerobic oxidation of glucose were inhibited.

Knox and his co-workers ${ }^{21}$ found that many of the cationic surface-active compounds which they tested in their metabolic studies would kill certain bacteria in concentrations that inhibited the metabolic reactions of the same organisms. They were able to demonstrate that cell-free bacterial enzymes can be inhibited by cationic detergent-protein ratios which are bactericidal for the intact cells. Furthermore, the killing and inhibition of bacterial growth are proportional to the detergent-bacteria ratio and not to the concentration of the detergent used. Their studies revealed, moreover, that certain enzymes may be specifically sensitive to the cationic quaternary ammonium germicides, which accounts for the metabolic inhibition, cell death, and permeability noted in bacteria treated with bactericidal amounts of the compounds.

Hotchkiss ${ }^{22}$ observed that the enzyme proteins or other vital parts of the bacterial cell appear to have a greater sensitivity to surface-active agents than do proteins in general. He noted that when bacteria are exposed to lethal concentrations of these compounds a leakage of nitrogen and phosphorus out of the cell would occur. This action can be demonstrated with cationic quaternary ammonium germicides, anionic surface-active compounds, cresols, bile salts, tyrocidin, and, to some extent, with nonionic surface-active agents. Germicides such as hydrogen peroxide, potassium permanganate, formaldehyde, organic mercurials, acridines, and the halogens failed to cause a leakage of cellular elements from bacteria.

Gale and Taylor ${ }^{23}$ confirmed, in part, the observations of Hotchkiss in that they were able to demonstrate that organisms exposed to tyrocidin showed a loss of internal free lysin and glutamic acid. A similar action was noted when a quaternary ammonium surface-active compound and an 
anionic detergent were used as the suspending media. No such effect was obtained with gramicidin, penicillin, sulfathiazole, or acriflavine.

The conductometric measurement procedure described by Eggenberger et al. ${ }^{24}$ has been the most recent approach to an explanation for the possible mechanism of action of surface-active quaternary ammonium germicides upon bacteria. Their findings reveal that cells exposed to certain of these compounds will release a highly conducting material as a means of protection for the organism. The rate of excretion of the protective material was found to increase with increased concentration of the germicide, terminating in a literal outpouring of the substance as the point of rapid killing is reached. Autoclaved bacteria treated with the same germicides failed to show this effect. Electron microscope photographs failed to reveal that this outpouring of conducting material was due to the rupture of the cells of the organism, inasmuch as the cells killed by the germicides were still intact.

The appearance of vacuoles and the enlargement of organisms exposed to penicillin as noted by Gardner ${ }^{25}$ may also be an effect of surface activity of the latter antibiotic. Hauser, Phillips, and Vavruch ${ }^{26}$ and Hauser ${ }^{27}$ were able to demonstrate that penicillin solutions resemble soapy water and possess surface-active properties. These investigators found that the antibiotic bears an electric charge similar to soaps and has a tendency to cling to surfaces with an opposite charge. Using ultraviolet light microscopy, they found that penicillin coats bacterial cells, as evidenced by the bacteria taking on the fluorescent properties of the antibiotic. The partial lysis of human tubercle bacilli in the presence of high concentrations of penicillin, as noted by Kirby and Dubos, ${ }^{28}$ may also be a function of the surface activity of the antibiotic.

Among the various effects of a quaternary ammonium surface-active germicide and anionic surface-active agents upon Trichomonas foetus reported by Lawrence ${ }^{29}$ was the gross shrinkage and complete fragmentation of the protozoal cells. In all the media in which cell fragmentation occurred, the surface tensions of the detergents were between 30 to 40 dynes per centimeter. Dissolution of motile trichomonads by quaternary ammonium germicides was also observed by MacDonald and Tatum, ${ }^{30}$ who studied the effects on $T r$. hominis, $T r$. vaginalis, and Tr. foetus.

Autolysis of protozoan cells, probably not unlike the action of quaternary ammonium germicides upon trichomonads, has been observed by Anderson, ${ }^{31}$ who exposed cultures of trypanosomes to the antibiotic, subtilin, which was also found to possess surface tension depressant activity. He also reported that cultures of trophozoites of Endamoeba histolyticum would "rupture" when exposed to the antibiotic.

An extensive series of investigations was carried out by Taft and Strandtmann, ${ }^{32-34}$ in which the effects of a quaternary ammonium surface-active germicide were determined against a variety of invertebrates. Among their observations was the rupturing effect of the compound on paramecia, colpidium, hypotriches, and planaria. While these and other organisms reacted differently to the germicide, this was not considered to be a phylogenetic difference but one due to the protective covering of the animals. 
The action of the surface-active compound was attributed, to a large extent, to its ability to lower surface tension and to its wetting properties.

Kuhn and Bielig ${ }^{35}$ found that proteins such as gelatin and egg albumen are precipitated in a water solution by quaternary ammonium compounds, whereas the latter fails to precipitate globulin. This latter phenomenon is attributed to the isoelectric point values of the proteins. Since proteins are precipitated only in the form of their anions, the negative-charged proteid ions will react with the positively charged molecule of the cationic compounds. This may also explain part of the mechanism of the killing action of the quaternary ammonium germicides on bacteria. Thus, the reaction of this group of compounds could be with the anion of the cell protein and the complexes essential for life in the bacterial cell. A similar explanation has been offered by Pfankuch and Kausche ${ }^{36}$ for the mechanism of action of quaternary ammonium surface-active germicides against plant viruses.

Anson ${ }^{37}$ noted that synthetic detergents and bile salts would denaturate proteins such as hemoglobin and egg albumen at their isoelectric points and keep these treated proteins in solution. Furthermore, if an excess of anionic or cationic detergent is added to bacteria, there is denaturation of enzyme proteins, some of which may be necessary for the lysis of certain organisms such as the pneumococci.

In studying the virucidal activity of saponin, sodium desoxycholate, and an anionic detergent against viruses, Burnet and Lush ${ }^{38}$ observed a close correlation between the concentrations of the agents capable of hemolyzing rabbit's red blood cells and the effect against herpes virus. Of the eleven viruses tested, only psittacosis virus was completely insusceptible to the several agents mentioned. They postulated from their findings that the inactivation within the virus cell is a function of some enzyme capable of disintegrating the surface of the virus particle in a manner analogous to that of the activity of the surface-active agents. A similar hypothesis was advanced by Smith $^{39}$ for the mechanism of action of bile salts against viruses. This investigator also considered that virus inactivation was due to the presence of an autolytic ferment, and the rapidity with which the susceptible viruses are completely inactivated by sodium desoxycholate compares with the phenomenon of the bile solubility of the pneumococcus. This suggests that the virus elementary bodies may actually be lysed by bile constituents. This should be readily revealed through electron microscopy.

Albert ${ }^{40}$ attributed the action of cationic antiseptics to their basic ions, which react with the acidic ions of microorganisms. Thus, these compounds have a greater effect against those organisms that contain an excess of acidic groups (nucleus and enzyme systems) over basic radicals. This may explain the general trend of greater activity of the quaternary ammonium germicides against $S$. aureus and other Gram-positive bacteria that contain a high ratio of acidic over basic groups than against Gram-negative organisms where the ratio is reversed.

Valko and DuBois ${ }^{41}$ found that an active quaternary ammonium compound may be markedly diminished in its antibacterial action by a less active quaternary ammonium salt, even when the compounds contain reasonably comparable constituents in the molecules. They attributed this 
interference as a reaction that occurs on the surface of the bacterial cell or within the cell itself. Thus, certain spaces on or in the cell will specifically select the harmless cations and protect the organism from the more toxic cations.

Dyar ${ }^{42}$ also noted a reaction between bacterial cell constituents and a surface-active mordant, which he used prior to the addition of an aqueous solution of Congo red to the organisms. Following washing and counterstaining with methylene blue, the cell walls of yeast and bacteria stained red, with definite evidence of a red precipitate. While the cytoplasm of the cells appeared to be shrunken away from the cell wall, he did not consider this indicative that the quaternary ammonium germicide had not penetrated the cell membrane. This was supported by evidence presented to show that the cytoplasm of the vegetative cells in the surrounding medium stained black when treated with a quaternary ammonium salt and a fat-dye, Sudan black B.

Dyar and Ordal ${ }^{43}$ and Kivela, Mallmann, and Churchill ${ }^{44}$ studied the electrophoretic mobilities of bacteria when treated with surface-active detergents. The first investigators found that anionic compounds produced no change, a slight change, or marked change in the electrophoretic mobility of the test organisms. Thus, if a change occurs, the concentration of the anionic compound at which this first occurs may vary considerably. With the cationic compound, there was a general trend of a decrease in charge on the cells, reversal of charge, and, finally, stabilization of charge. Kivela and his associates observed that by merely washing vegetative cells and spores of bacteria, following treatment with a quaternary ammonium germicide, one can restore the normal electrical charge of the cells. While revival of the washed bacterial spores could also be demonstrated by bacteriological culturing, the vegetative organisms, on the other hand, could not be revived by this treatment.

The most recent trends in investigations on the mechanism of action of surface-active agents upon bacteria involves studies upon the latter in the presence of human and animal phagocytes. Berry, Starr, and Haller ${ }^{45}$ found that certain compounds would at least double the number of bacteria ingested by human neutrophils as compared to control specimens in the absence of the surface-active detergents. The same compounds injected intraperitoneally into mice were also found to cause an elevation of phagocytic activity. Yet these investigators were unable to show any increased protection in Salmonella typhimurium-infected mice by the administration of the compounds that were active in the phagocyte-bacteria tests in vitro. They explained the latter as being due to the fact that no change in phagocytosis could be observed in vitro when the blood cells and bacteria were incubated before they were combined with the detergents.

Nungester and Ames ${ }^{46}$ also reported on the influence of surface-active compounds upon phagocytic activity. Their studies reveal that some of the quaternary ammonium salts will materially increase the activity of phagocytes not only in vitro but also in vivo. Evidence for the latter is found in their data where mice infected with fatal doses of the pneumococcus were protected by treatment with a quaternary ammonium com- 
pound. The concentration of the germicide used was not bacteriostatic for the organisms in vitro.

There are many references in the literature to the use of "neutralizers," "inactivators," and "antidotal" substances for the evaluation of the antibacterial activity of germicides, disinfectants, "sanitizers," and chemotherapeutic agents. Klarmann ${ }^{47}$ has compiled one of the most complete and comprehensive reviews on this general subject, and, for this reason, mention will be made solely of the several substances that have been recommended for the inactivation of the germicidal action of quaternary ammonium compounds.

Domagk ${ }^{48}$ was first to call attention to the fact that anionic detergents (soap) will inactivate the surface-active cationic detergents. Soap has been used since then by many investigators to distinguish between the bactericidal and bacteriostatic activity of quaternary ammonium salts (James and Eckfeldt, ${ }^{48,}{ }^{50}$ Pressman and Rhodes, ${ }^{51}$ DuBois and Bibblee, ${ }^{52}$ etc.).

Baker, Harrison, and Miller ${ }^{53}$ were able to show that certain synthetic anionic detergents would also inactivate the germicidal properties of cationic detergents. The former compounds have also been used by Rahn, ${ }^{54}$ Weber and Black, ${ }^{55}$ and others for this purpose. Valko and DuBois ${ }^{41}$ reported that bacteria which are apparently "killed" by a quaternary ammonium germicide may be revived by the addition of a high molecular weight anion, provided treatment with the latter occurs within 10 to 30 minutes. Klein and Kardon, ${ }^{56}$ on the other hand, were able to demonstrate that "reversal" of quaternary ammonium activity cannot be produced once the organisms have been exposed to germicidal concentrations of the compounds. They found that the addition of an anionic detergent to the treated bacterial suspensions merely interrupted the continued action of the cationic detergents, thereby permitting surviving organisms to grow.

Unlike the ionic reaction between anionic and cationic compounds in the interference of the germicidal action of quaternary ammonium compounds by phospholipids, Baker and her co-workers ${ }^{53}$ demonstrated the protective action of lecithin, cephalin, and sphingomyelin on bacteria that were subsequently exposed to lethal concentrations of the cationic germicides. Note was made of the fact that the lipids were ineffective unless they were added to the suspension of organisms just before or at the same time as the quaternary ammonium salts.

Favorable results on the use of lecithin alone or in combination with other substances for the inactivation of cationic germicides have also been reported by Quisno, Gibby, and Foter, ${ }^{67}$ Armbruster and Ridenour, ${ }^{68}$ and others. The presence of phospholipids or related substances may also account for the inactivating action of the liver broth used by Zeissler and Günther, ${ }^{69}$ and the oxgall employed by Klarmann and Wright ${ }^{60}$ in their quaternary ammonium investigations.

Brief mention may be made of the studies of Goetchius, ${ }^{61}$ in which a sodium salt of a condensed aryl sulfonic acid was used as a cationic inhibitor, and the observations of Lawrence, ${ }^{62}$ which indicated that a naphthylene sulfonic acid would neutralize the antibacterial activity of quaternary ammonium compounds. 
The most recent trend in the use of "inactivators" for distinguishing bacteriostatic from bactericidal activity of cationic germicides is the addition of the former agents to the sample at the time of collection, plus the incorporation of the same inactivator in the agar in which a determination of the numbers of viable bacteria is to be made (Weber and Black ${ }^{63}$ ).

Although this concludes this résumé of the literature on the mechanism of action and neutralizing agents for certain surface-active germicides, it is not to be inferred that the review is a complete one. Selection of various publications has been made to indicate the various theories and methods that have been proposed on these subjects. Some of this material will be supplemented and new approaches to methods are envisioned from the papers that follow.

\section{Bibliography}

1. Jacoss, W. A. \& M. Hetoelberger. 1915. The quaternary salts of hexamethylenetetramine. III. Monohalogenacylated aromatic amines and their hexamethylenetetraminium salts. J. Biol. Chem. 21: 103.

2. JACOBS, W. A. \& M. H zTOECBERGER. 1915. The quaternary salts of hexamethylenetetramine. IV. Monohalogenacylated simple amines, ureas, and urethanes, and the hexamethylenetetraminium salts derived therefrom. J. Biol. Chem. 21: 145.

3. JACOBS, W. A. \& M. H IIJELBER FER. 1915. The quateraary salts of hexamethylenetetramine. V. Monohalogenacetyl derivatives of aminoalcohols and the hexamethylenetetraminium salts derived therefrom. J. Biol. Chem. 21: 403.

4. JACOBS, W. A. \& M. HEIDELBERGER. 1915. The quaternary ammonium salts of hexamethylenetetramine. VI. Halogenethyl esters and ethers and their hexamethylenetetraminium salts. J. Biol. Chem. 21: 439 .

5. JACOBS, W. A. \& M. HEIDELBERGER. 1915. The quaternary salts of hexamethylenetetramine. VII. $\omega$-halogen derivatives of aliphatic-aromatic ketones and their hexamethylenetetraminium salts. J. Biol. Chem. 21: 455 .

6. JaCOBS, W. A. \& M. HEIDELBERGER. 1915. The quaternary salts of hexamethylenetetramine. VIII. Miscellaneous substances containing aliphatically bound halogen and the hexamethylenetetraminium salts derived therefrom. J. Biol. Chem. 21: 464 .

7. JACOBS, W. A. \& M. HEIDELBERGER. 1915. The quaternary salts of hexamethylenetetramine. I. Substituted benzyl halides and the hexamethylenetetraminium salts derived therefrom. J. Biol. Chem. 20: 659.

8. JACOBS, W. A. \& M. HEIDELBERGER. 1915. The quaternary salts of hexamethylenetetramine. II. Monohalogenacetylbenzylamines and their hexamethylenetetraminium salts. J. Biol. Chem. 20: 685 .

9. JACOBS, W. A. 1916. The bactericidal properties of the quaternary salts of hexamethylenetetramine. I. The problem of the chemotherapy of experimental bacterial infections. J. Exptl. Med. 23: 563.

10. CowLES, P. B. 1938. The germicidal power of some alcohols for Bacterium typhosum and Stapleylococtus aureus, and its relation to surface tension. Yale J. Biol. and Med. 11: 127.

11. Harris, R. S. \& J. W. M. Bunker. 1932. Bacterial detoxification. Proc. Am. Acad. Arts Sci. 67: 147.

12. Neter, E. 1942. Effect of alkyldimethylbenzylammonium chlorides (Zephiran) upon tetanus toxin. Proc. Soc. Exptl. Biol. Med. 51: 254.

13. Neter, F. 1942. Effects of alkyldimethylbenzylammonium chlorides upon plasma coagulation by staphylococcus and fibrinolysis by streptoccus. Proc. Soc. Exptl. Biol. Med. 51: 256.

14. HolmEs, L. F. 1941. The effect of surface tension depressants on certain serological systems. Yale J. Biol. \& Med. 14: 155.

15. Miller, B. F., Z. BAKer, \& R. W. Harrison. 1939. Action of a quaternary ammonium type of wetting agent on metabolism of microorganisms associated with dental caries. Proc. Soc. Exntl. Biol. Med. 42: 705.

16. Milter, B. F. \& Z. BAKer. 1940. Inhibition of bacterial metabolism by synthetic detergents. Science 91: 624 . 
17. Baker, Z., R. W. Harrison, \& B. F. Miller. 1941. Action of synthetic detergents on the metabolism of bacteria. J. Exptl. Med. 73: 249.

18. BaKer, Z., R. W. HarRison, \& B. F. MiLler, 1941. The bactericidal action of synthetic detergents. J. Exptl. Med. 74: 611.

19. Ordal, E. J. \& A. F. Borg. 1942. Effect of surface active agents on oxidations of lactate by bacteria. Proc. Soc. Exptl. Biol. Med. 50: 332.

20. Sevag, M. G. \& O. A. Ross. 1944. Studies on the mechanism of the inhibitory action of Zephiran on yeast cells. J. Bact, 48; 677.

21. Knox, W. E., V. H. Auerbach, K. Zarudnaya, \& M. Spirtes. 1949. The action of cationic detergents on bacteria and bacterial enzymes. J. Bact. 68: 443.

22. Hotchisiss, R. D. 1946. The nature of the bacterial action of surface-active agents. Ann. N. Y. Acad. Sci. 46: 479.

23. Gale, E. F. \& E. S. TAYLOR. 1946. Action of tyrocidine and detergents in liberating amino acids from bacterial cells. Nature 167: 549 .

24. Eggenberger, D. N., L. A. Harriman, M. J. McClory, D. Noel, \& H. J. Harwood. 1950. Conductometric studies of bactericidal mechanisms. Ann. N. Y. Acad. Sci. $63(1): 105$.

25. GARDNER, A. D. 1940. Morphological effects of penicillin on bacteria. Nature 146: 837.

26. Hadjer, E. A., J. W. Phillirs, \& I. Vavrdch. 1948. Antibiotic colloids. I. Penicillin. 22nd Nat. Colloid Symposium. Am. Chem. Soc. Abst. Drug Trade News 23: 42.

27. Hauser, E. A. 1950. The colloidal nature of antibiotics. Ann. N. Y. Acad. Sci. $63(1): 18$.

28. KIRBY, W. M. M. \& R. J. Duвos. 1947. Effect of penicillin on the tubercle bacillus in vitro. Proc. Soc. Exptl. Biol. Med. 66: 120 .

29. LAWRENCE, C. A. 1946. Rocalina - a quaternary ammonium compound of high germicidal activity. Acta Med. Orientale 5: 363 .

30. MacDonald, E. M. \& A. L. TATuM. 1948. In vitro action of various chemical agents on Trichomonas hominis, Trichomonas vaginalis and Trichomonas foetus. J. Immunol. 69: 301 .

31. Anderson, H. 1947. New surface antibiotics. J. Invest. Dermat. 8: 25.

32. TAFT, C. H. 1946. Some observations on the effects of a mixture of high molecular alkyldimethylbenzylammonium chlorides on various invertebrates. Texas Repts., Biol. Med. 4: 27.

33. TAFT, C. H. 1945. The effects of a mixture of high molecular alkyldimethylbenzylammonium chloride on the isolated heart of Limulus polyphemus. Proc. Trans. Texas Acad. Sci. 28: 98.

34. Taft, C. H. \& R. W. StrandtmanN. 1945. The use of alkyldimethylbenzylammonium chlorides in mosquito control. Federation Proc. 4: 136.

35. KUHN, R. \& H. J. Brelig. 1940. Ueber invertseifen: I. Die einwirkung von invertseifen auf eiweissstoffe. Ber. 73: 1080.

36. Pfankuch, E. \& G. A. Kadsche. 1942. Ueber die wirkung oberflachäktiver verbindungen auf virusproteine. Biochem. Z. 312: 72.

37. Anson, M. L. 1939. The demonstration of proteins by synthetic detergents and bile salts. J. Gen. Physiol. 23: 239.

38. BURNET, F. M. \& D. LuSH. 1940. The action of certain surface-active agents on viruses. Australian J. Exptl. Biol. Med. Sci. 18: 141.

39. Sмrth, W. 1939. The action of bile salts on viruses. J. Path. Bact. 48: 557.

40. Albert, A. 1942. Chemistry and physics of antiseptics in relation to mode of action. Lancet 2: 633 .

41. Valko, E. I. \& A. S. DuBoIs. 1944. The antibacterial action of surface-active cations. J. Bact. 47: 15.

42. DyAR, M. T. 1947. A cell wall stain employing a cationic surface-active agent as a mordant. J. Bact. 63: 498.

43. DyAR, M. T. \& E. J. ORDAL. 1946. Electrokinetic studies on bacterial surfaces. I. The effects of surface-active agents on electrophoretic mobilities of bacteria. J. Bact. $\overline{5} 1: 149$.

44. Kivela, E. W., W. L. Mallmann, \& E. S. Churchill. 1948. Physical action of surface-active cations upon bacteria. J. Bact. Б5: 565 .

45. Berry, L. J., R. W. Starr, \& E. C. Haller. 1949. The effect of surface-active agents on phagocytosis. J. Bact. 57: 603 .

46. Nungester, W. J. \& A. M. AmEs. 1949. The use of quaternary ammonium compounds in the treatment of Type I pneumococcus infections in mice. Proc. 49th Gen. Meet. Soc. Am. Bact.: 98, 
47. KlarmanN, E. G. 1950. The role of antagonisms in the evaluation of antiseptics: Ann. N. Y. Acad. Sci. 63(1): 123.

48. Domagk, G. 1935. Eine neue Klasse von desinfektionsmitteln. Deut. med. Wochschr. 61: 829.

49. JAMES, L. H. 1947. Quaternaries vs. phenolics: Germicidal effectiveness of some quaternary and phenolic compounds reported with time-survival numbers of $E$. typhosa and $S$. aureus. Soap Sanit. Chemicals 23: 125.

50. EckFELDT, G. \& L. H. James. 1947. Quaternaries vs. phenols: The germicidal effectiveness of some quaternary and phenolic compounds reported together with time-survival numbers of $E$. typhosa and $S$. aureus. Soap Sanit. Chemicals 23: 157.

51. Pressman, R. \& J. C. Rhodes. 1946. Sources of error in germicidal activity tests with quaternary ammonium compounds. Soap Sanit. Chemicals 22: 137.

52. Dubors, A. S. \& D. D. Dibbles. 1947. The influence of pretreating bacteria with anionic agents on the antibacterial action of cationic germicides. J. Bact. 53: 251.

53. Baker, Z., R. W. HaRrison, \& B. F. Miller. 1941. Inhibition by phospholipids of the action of synthetic detergents on Bacteria. J. Exptl. Med. 74: 621.

54. RAHN, O. 1947. Advisibility of some proposed changes for the evaluation of disinfectants. J. Am. Pharm. Assoc., Sci. Ed. 36: 134.

55. WEBER, G. R. \& L. A. BLACK. 1947. Inhibitors for neutralizing the germicidal action of quaternary ammonium compounds. Proc. 47 th Gen. Meet. Soc. Am. Bact.: 44.

56. KLEIN, M. \& Z. G. KARDON. 1947. The "reversal," neutralization, and selectivity of germicidal cationic detergents. J. Bact. 54: 245.

57. QUISNo, R., I. W. GibBy, \& M. J. Forer. 1946. A neutralizing medium for evaluating the germicidal potency of quaternary ammonium salts. Am. J. Pharm. 118: 320.

58. Armbruster, E. H. \& G. M. Ridenour. 1947. A new medium for study of quaternary bactericides. Soap Sanit. Chemicals 23: 119.

59. Zeissler, J. \& O. Günther. 1939. Schlusswort zu den entgegnungen Brekenfelds auf unsere arbeit: "Kann durch kochen in Zephirol-bzw. Quartamon-lösungen sterilisiert werden." Zentr. Bakt. Parasitenk. Orig. 144: 409.

60. KiaRmanN, E. G. \& E. S. WRIGHT. 1948. Concerning quaternaries: Additional data support "semi-micro" technic in testing quaternary germicides. Soap Sanit. Chemicals. 24: 155 .

61. Goetchios, G. R. 1948. An inexpensive synthetic, non-detergent inactivator for quaternary ammonium germicides. Proc, 48th Gen. Meet. Soc. Am. Bact.: 29.

62. LAWRENCE, C. A. 1948. Inactivation of the germicidal action of quaternary ammonium compounds. J. Am. Pharm. Assoc., Sci. Ed. 37: 57.

63. WEBER, G. R. \& L. A. BLACK. 1948. Laboratory procedure for evaluating practical performance of quaternary ammonium and other germicides proposed for sanitizing food utensils. Am. J. Pub. Health. 38: 1405. 